\title{
Postmortem transport in fossil and modern shelled cephalopods
}

\author{
Margaret M. Yacobucci ${ }^{\text {Corresp. } 1}$ \\ ${ }^{1}$ Department of Geology, Bowling Green State University, Bowling Green, Ohio, United States \\ Corresponding Author: Margaret M. Yacobucci \\ Email address: mmyacob@bgsu.edu
}

The chambered shells of cephalopod mollusks, such as modern Nautilus and fossil ammonoids, have the potential to float after death, which could result in significant postmortem transport of shells away from living habitats. Such transport would call into question these clades' documented biogeographic distributions and therefore the many (paleo)biological interpretations based on them. It is therefore imperative to better constrain the likelihood and extent of postmortem transport in modern and fossil cephalopods. Here, I combine the results of classic experiments on postmortem buoyancy with datasets on cephalopod shell form to determine that only those shells with relatively high inflation are likely to float for a significant interval after death and therefore potentially experience postmortem transport. Most ammonoid cephalopods have shell forms making postmortem transport unlikely. Data on shell forms and geographic ranges of early Late Cretaceous cephalopod genera demonstrate that even genera with shell forms conducive to postmortem buoyancy do not, in fact, show artificially inflated biogeographic ranges relative to genera with non-buoyant morphologies. Finally, georeferenced locality data for living nautilid specimens and dead drift shells indicate that most species have relatively small geographic ranges and experience limited drift. Nautilus pompilius is the exception, with a broad Indo-Pacific range and drift shells found far from known living populations. Given the similarity of $N$. pompilius to other nautilids in its morphology and ecology, it seems unlikely that this species would have a significantly different postmortem fate than its close relatives. Rather, it is suggested that drift shells along the east African coast may indicate the existence of modern (or recently extirpated) living populations of nautilus in the western Indian Ocean, which has implications for the conservation of these cephalopods. 


\section{Postmortem transport in fossil and modern shelled cephalopods}

3 Margaret M. Yacobucci

4 Department of Geology, Bowling Green State University, Bowling Green, Ohio, 43403, USA

5

6 Email address: mmyacob@,bgsu.edu

7 


\section{Abstract}

The chambered shells of cephalopod mollusks, such as modern Nautilus and fossil

10 ammonoids, have the potential to float after death, which could result in significant postmortem

11 transport of shells away from living habitats. Such transport would call into question these

12 clades' documented biogeographic distributions and therefore the many (paleo)biological

13 interpretations based on them. It is therefore imperative to better constrain the likelihood and

14 extent of postmortem transport in modern and fossil cephalopods. Here, I combine the results of

15 classic experiments on postmortem buoyancy with datasets on cephalopod shell form to

16 determine that only those shells with relatively high inflation are likely to float for a significant

17 interval after death and therefore potentially experience postmortem transport. Most ammonoid cephalopods have shell forms making postmortem transport unlikely. Data on shell forms and geographic ranges of early Late Cretaceous cephalopod genera demonstrate that even genera with shell forms conducive to postmortem buoyancy do not, in fact, show artificially inflated biogeographic ranges relative to genera with non-buoyant morphologies. Finally, georeferenced locality data for living nautilid specimens and dead drift shells indicate that most species have relatively small geographic ranges and experience limited drift. Nautilus pompilius is the exception, with a broad Indo-Pacific range and drift shells found far from known living populations. Given the similarity of $N$. pompilius to other modern nautilids in its morphology and ecology, it seems unlikely that this species would have a significantly different postmortem fate than its close relatives. Rather, it is suggested that drift shells along the east African coast may indicate the existence of modern (or recently extirpated) living populations of nautilus in the western Indian Ocean, which has implications for the conservation of these cephalopods. 


\section{Introduction}

\section{The problem of postmortem transport}

Biogeographic distributions strongly influence the ecology, evolution, and extinction of clades. While scientists studying modern organisms can collect data on the observed locations of sampled living specimens, paleontologists must assume that fossil localities provide an accurate estimate of the group's living geographic range. For most marine animal groups, especially benthic invertebrates, that assumption appears to work well, as their hard parts tend to be buried and fossilized at or near their life locations (Kidwell \& Flessa, 1996; Tomašových \& Kidwell, 2009; Tyler \& Kowalewski, 2017). However, cephalopod mollusks with chambered shells present a special challenge — once their soft parts are removed, cephalopod shells can float after death and therefore be picked up and transported by surface currents (Fig. 1). This postmortem transport or "drift" has been observed in living nautilid species, but how commonly it occurs in ancient cephalopod groups has been debated in the scientific literature for over 100 years (Walther, 1897; Reyment 1958, 1970, 1973, 2008; Stenzel 1964; House 1973, 1987; Chamberlain \& Weaver 1978; Wani et al. 2005; Mapes et al 2010a; Wani and Gupta, 2015; Yacobucci, 2015). If postmortem transport was frequent and extensive, the geographic distributions of fossil cephalopods should be considered unreliable proxies for living ranges. Biogeographic studies of fossil cephalopods require some assurance that locality data are meaningful, especially as paleontologists investigate paleobiogeographic processes with more quantitative analytical methods (Brayard, Escarguel \& Bucher, 2007; Dera et al., 2011; Brayard et al., 2015; Ifrim, Lehmann \& Ward, 2015; Korn \& De Baets, 2015; Lehmann et al., 2015; Zacaï et al., 2106, 2017; Rojas et al., 2017; Wani, 2017; Yacobucci, 2017). Also, as modern nautilids experience greater fishery pressure and habitat disruption due to climate change and 
54 other anthropogenic impacts, conservation efforts will need to accurately assess population

55 distributions (Dunstan, Alanis \& Marshall, 2010; Dunstan, Bradshaw \& Marshall, 2011;

56 Dunstan, Ward \& Marshall, 2011a, 2011b; Sinclair et al., 2011; De Angelis, 2012; Barord et al.,

57 2014; Williams et al., 2015, Ward, Dooley \& Barord, 2016; Saunders, Greenfest-Allen \& Ward,

58 2017). It is therefore imperative to determine the likely frequency of postmortem transport in

59 both fossil and modern shelled cephalopods.

In the 19th and early 20th centuries, some workers noted that the small geographic

61

62

63

64

65

transport, while others argued that the lack of preserved soft parts (particularly for ammonoids) indicated that the shells must have drifted for some time before sinking to the seafloor (Walther, 1897; Reyment, 1958; it should be noted that this lack of soft parts could potentially also be explained by a high level of ammonia in the soft tissues, which prevents mineralization of the decaying tissues, see Clements et al., 2017). The "drift" argument was bolstered by observations in the mid-20th century of varyingly broken and encrusted shells of modern Nautilus on beaches and other coastal settings in Australia (Iredale, 1944), Japan (Kobayashi, 1954), Thailand (Hamada, 1964; Toriyama et al. 1965), and the Bay of Bengal (Teichert, 1970). These authors inferred from these observations that Nautilus shells were being transported by ocean currents away from living populations, likely in the Philippines, Indonesia, and New Caledonia. Reyment (1958) provided a review of much of this earlier literature. Reyment claimed that postmortem drift was common in both modern and fossil shelled cephalopods (which he described as the minority viewpoint at the time) and investigated the buoyancy of empty shells to determine which shell characteristics were related to greater buoyancy and therefore postmortem transport (see "Cephalopod shell buoyancy" below). Reyment continued throughout his career to argue 
77 vigorously that postmortem drift in cephalopods was "the rule rather than the exception"

78 (Reyment, 1970, 1973, 2008) and influenced the position of many other paleontologists (e.g.,

79 Stenzel, 1964; House, 1973, 1987; Cecca, 2002) as well as biologists (e.g., Reid, 2016). For

80 example, Chamberlain \& Weaver (1978) claimed that modern nautilid shells "often" rise to the

81 surface after death and are "often dispersed by currents--sometimes on an impressive

82 scale...thousands of miles from the habitat of the animals that build them....and similar behavior is

83 inferred for many fossil cephalopods..." (Chamberlain \& Weaver, 1978, p. 673-674)

84 On the other hand, the extent to which postmortem transport has affected the distribution

85 of fossil cephalopods has been questioned. Many fossil localities include very large numbers of

86 well-preserved, intact shells, which is hard to explain by postmortem transport (Kennedy \&

87 Cobban, 1976). It is also well-established that many cephalopod taxa or morphotypes are

88 strongly tied to particular depositional environments and sedimentary facies, implying fidelity of

89 dead shells to their living habitat (Tanabe, 1979; Lukeneder, 2015). Paleontologists have noted

90 that postmortem transport is likely to remove drift shells from the fossil record entirely, as they

91 degrade over time and end up destroyed when carried by currents into high energy shoreline

92 environments (Hewitt, 1988; Maeda \& Seilacher, 1996; Maeda, Mapes \& Mapes, 2003; Mapes

93 et al., 2010b; Hembree, Mapes \& Goiran, 2014; Tomašových et al., 2016, 2017). Fossil

94 cephalopods, therefore, likely represent shells that sank soon after death.

95 Chamberlain, Ward \& Weaver (1981) used buoyancy calculations to argue that most

96 ammonoids, especially those with shells less than $5 \mathrm{~cm}$ diameter or found in deeper water

97 settings (where ambient hydrostatic pressure is high), would quickly sink to the sea floor after

98 the removal of soft parts, as water flooded the phragmocone (the chambered portion of the shell).

99 A similar argument has been made for Paleozoic and Mesozoic nautiloids (Hewitt \& 
100 Westermann, 1996; Chirat, 2000), although Chirat (2000) suggested that the Cenozoic nautilid

101 Aturia Bronn, 1838 experienced unusually extensive drift because its very long septal neck

102 would have slowed the rate of flooding. Wani et al. (2005) conducted experiments on modern

103 Nautilus pompilius Linnaeus, 1758 and showed that the phragmocone floods quickly once the

104 mantle tissue is detached, especially if the shell is small. They argued that only shells over $20 \mathrm{~cm}$

105 in diameter were likely to experience significant postmortem transport, consistent with their

106 claim that observations of long-distance postmortem drift in modern nautilids — while sometimes

107 dramatic - are actually quite rare.

108 Mapes and colleagues (2010a) pointed out that we typically only encounter modern

109 nautilid shells that have floated into nearshore settings and have little firsthand information about

110 what happens to nautilid shells that sink quickly to the sea floor. Remarkable data from dredged

111 specimens of Nautilus macromphalus Sowerby, 1848 show nautilid shells do indeed accumulate

112 on the sea floor in deep water, near their living habitats (Roux, 1990; Roux et al., 1991; Mapes et

113 al. 2010a; Seuss et al., 2015; Tomašových et al., 2016, 2017). Evidence of bioerosion and

114 encrustation has been used as evidence for the duration of transport and exposure at the sea floor

115 in both modern (Seuss et al., 2015; Tomašových et al., 2016, 2017) and fossil nautilids (Luci \&

116 Cichowolski, 2014) and in ammonoids (Luci, Cichowolski \& Aguirre-Urreta, 2016). Such

117 detailed taphonomic analyses are necessary, as workers have argued that one must not assume

118 postmortem transport but rather search for evidence of it in specific cases (Wani, 2004; Wani et

119 al., 2005; Wani \& Gupta, 2015; Yacobucci, 2015).

\section{Cephalopod shell buoyancy}

$121 \quad$ For a cephalopod shell to experience postmortem drift, it must first become positively

122 buoyant after the death of the animal. Numerous workers have investigated the buoyancy of 
123 cephalopod shells, both during life and after death, via physical experiments and mathematical

124 models (Trueman, 1941; Denton \& Gilpin-Brown, 1966; Westermann, 1971; Chamberlain \&

125 Weaver, 1978; Ward \& Martin, 1978; Ward \& Greenwald, 1982; Greenwald \& Ward, 1987;

126 Jacobs \& Chamberlain, 1996; Kröger, 2002; Hammer \& Bucher, 2006; Naglik, Rikhtegar \&

127 Klug, 2014; Tajika et al., 2014; Hoffman et al., 2015; Naglik et al., 2015), with new imaging and

128 computational techniques (Hoffmann \& Zachow, 2011; Hoffmann et al., 2015; Lemanis et al.,

129 2015; Peterman, Barton \& Yacobucci, 2018) enabling ever more sophisticated analyses. Workers

130 have established that, in life, modern nautilids are generally neutral to slightly negatively

131 buoyant (Ward \& Martin, 1978; Greenwald \& Ward, 1987). Newly formed chambers of the

132 phragmocone are emptied of liquid slowly, at a rate of about $1 \mathrm{~mL}$ per chamber per day, via the

133 siphuncle, a tube of tissue extending back from the soft body of the animal through openings in

134 the septal walls that define the chambers (Ward \& Martin, 1978). Modern nautilids are capable

135 of partially refilling empty chambers in 10 to 30 hours (for a rate of about $2 \mathrm{~mL} /$ day) in response

136 to sudden increases in buoyancy, for instance, if some of its shell is removed by a predator

137 (Ward \& Greenwald, 1982). This partial refilling, though, may be insufficient for the animal to

138 regain neutral buoyancy.

139 After a shelled cephalopod dies and some or all of its soft parts are removed, and

140 assuming it died at a shallow enough depth not to sink immediately (Chamberlain, Ward \&

141 Weaver, 1981; Maeda \& Seilacher, 1996), the shell will become positively buoyant and float

142 until the phragmocone is filled by seawater moving through the siphuncular opening (assuming

143 the phragmocone is intact) (Wani \& Gupta, 2015). A critical question is how quickly this

144 flooding of the phragmocone happens. Wani et al. (2005) conducted taphonomic experiments in

145 which freshly killed N. pompilius in the Philippines were set on deep (320 m) and shallow (50 m) 
146 seafloors. Soft parts were left within the shells. They found that flooding of the phragmocone did

147 not occur immediately postmortem, but that most shells at both depths were flooded within 3

148 (shallow) to 7 (deep) days, as the mantle's attachment to the last septum failed. In the few days

149 before flooding of the phragmocone began, the dead cephalopod presumably remained neutral to

150 slightly negatively buoyant, as in life; the dead animal would therefore not be transported by

151 surface currents during this interval, but some transport via deeper-water currents might occur

152 (although Wani et al.'s (2005) experimental design did not test for this). Flooding began when

153 decaying mantle tissue pulled away from the back of the body chamber; presumably removal of

154 soft parts by predation or scavenging would hasten the initiation of chamber filling. Wani et al.

155 (2005) further argued that the rate of flooding would be a function of the radius, thickness, and

156 length of the siphuncular tube. Since fossil ammonoids possessed a siphuncle 1.5 to 3 times as

157 long as that of modern N. pompilius, they predicted that ammonoid phragmocones would flood

158 faster than modern nautilids.

159 Reyment (1973) explicitly connected variations in shell form to the likelihood of positive

160 postmortem buoyancy in ammonoids. He used modern nautilid shells and plastic models of a

161 variety of fossil cephalopod shell morphotypes in laboratory experiments to identify how

162 differing shell shapes produced different degrees of buoyancy in the empty shells. Plastic models

163 were constructed based on molds of actual fossil specimens. These included three ceratite

164 ammonoid taxa (Ceratites (Acanthoceratites) spinosus Philippi, Ceratites nodosus (von Buch),

165 and Discoceratites sp. (no author given)), which are similar in most shell parameters and

166 ornamentation, but show a continuum of more compressed (Discoceratites sp.) to more inflated

167 (C. (A.) spinosus) whorl shapes. Flotation experiments were conducted on these models to

168 determine how much weight would need to be added to cause the floating empty shells to sink. 
169 Reyment (1973) found that the ceratite shells with more inflated whorl sections were more

170 buoyant, that is, more weight needed to be added to the shell to counteract buoyancy forces and

171 cause the shell to sink. The ceratite models showed that these shell shapes would have required

172 more water in their phragmocone chambers when alive than modern Nautilus pompilius does, in

173 order to maintain neutral buoyancy. Reyment (1973) attributed this difference to the ceratites'

174 shells being more evolute and with a longer body chamber that Nautilus.

175 Having found experimentally that shell parameters like coiling, inflation, and body

176 chamber length are important determinants of postmortem buoyancy, Reyment (1973) argued

177 that quantitative analysis of cephalopod shell shape would provide a more efficient way of

178 investigating the hydrostatics of fossil shells than the time-consuming and expensive physical

179 modeling and tank experiments he conducted. To demonstrate this, he performed a principal

180 coordinates analysis on five shell shape parameters (shell diameter, maximum inflation, body

181 chamber length, ventral inflation, and umbilical width) for 42 Mesozoic ammonoid species. The

182 position of each species on a plot of the first two principal coordinates indicates its overall shell

183 shape (Fig. 2). Based on his experimental results, Reyment then mapped out on the plot which

184 shell shapes would have more or less buoyancy postmortem, that is, need more or less water

185 flooding into the phragmocone to sink. He concluded that serpenticones (narrow shells with a

186 wide umbilicus, plotting high on the second principal axis) and oxycones (disc-shaped shells

187 with a high whorl expansion rate, plotting high on the first principal axis but low on the second

188 principal axis) were less buoyant while the more inflated spherocone shells (plotting low on the

189 first principal axis) showed higher postmortem buoyancy. Hence, it can be predicted that

190 spheroconic ammonoids would be more likely to experience extensive postmortem transport.

191 Linking shell form, postmortem transport potential, and geographic distribution 
193 cephalopods (2008), his own work (1973) suggested a more complex relationship between shell

194 form, postmortem buoyancy, and transport potential. Reyment's (1973) morphospace for

195 Mesozoic ammonoids (Fig. 2) closely resembles the ternary Westermann Morphospace devised

196 by Ritterbush \& Bottjer (2012) to capture morphological variations in regularly coiled

197 ammonoids (Fig. 3), with three end-member forms representing serpenticones, oxycones, and

198 spherocones. This resemblance is understandable given the overlap in shell shape parameters that

199 the two approaches use to construct their morphospaces. Westermann Morphospace has the

200 advantage of being expressed in a standardized frame of reference, making comparisons among

201 any taxa possible, in contrast to more traditional factor analytic techniques that define axes that

202 apply only to the specimens used to define them. Westermann Morphospace, then, becomes a

203 useful framework to assess the link between shell form and postmortem transport potential.

204 Given the ongoing debate about the frequency of postmortem transport in both fossil and 205 modern shelled cephalopods and the importance of this question to our understanding of the 206 geographic distributions of these groups, the present research has three goals:

(1) To determine the relationship between cephalopod shell form and postmortem transport potential,

(2) To test the hypothesis that fossil cephalopods with higher postmortem transport

210 potential will show artificially larger geographic ranges than cephalopods with lower transport

211 potential,

212 (3) To assess the extent of postmortem transport in modern nautilid species.

213 Ultimately, the intention of this work is to enable fossil cephalopod workers to use shell forms to

214 better predict the likelihood of postmortem transport and to evaluate their confidence in the use 
215 of geographic ranges derived from fossil localities as a proxy for the living geographic ranges of

216 the groups under study. In addition, analysis of the geographic distribution of modern living and

217 dead drift nautilid shells will help researchers better evaluate the geospatial extent of these

218 charismatic but threatened species.

219

220 Materials \& Methods

221 Datasets

222 Four datasets were compiled for morphometric and geographic analyses. All datasets are 223 available as Supplementary Material.

224 (1) Shell shape data for taxa included in Reyment (1973) plus modern nautilids.

225 Unfortunately, Reyment did not include the raw shell shape data upon which he performed the

226 principal coordinates analysis shown in Fig. 2. Therefore, for each of the genera he included,

227 images of fossil specimens were located in the ammonoid Treatise volumes (Arkell et al., 1957;

228 Wright, Callomon \& Howarth, 1996). In some cases, the images were of the same species

229 Reyment used, while in other cases a congeneric species had to be used, based on the availability

230 and quality of preservation of the specimens. Not having access to Reyment's specimens, the

231 rationale for using the ammonoid Treatise volume was to use a widely available and well-known

232 publication as a data source, making the data set more easily replicable. These images were used

233 to measure the five shell shape characters necessary for determining a taxon's position in

234 Westermann Morphospace (Ritterbush \& Bottjer, 2012): shell diameter (D), width of last whorl

235 (b), height of last whorl (a), height of whorl $180^{\circ}$ back from last whorl (a'), and umbilical

236 diameter (UD) (Fig. 4). In total, 38 species were included in this dataset. Reyment's assessment

237 of the degree of postmortem buoyancy for each taxon (Fig. 2) was used to assign each species to 
238 one of three categories: buoyant, intermediate, or non-buoyant. Note here that "non-buoyant"

239 really means minimally buoyant shells that would sink with little additional weight added as

240 water flooding the phragmocone, as opposed to "buoyant" shells that would require more weight

241 to be added in order to sink.

242 For comparison, shell shape measurements were also made on examples of four living

243 nautilid taxa: Nautilus belauensis Saunders, 1981, N. macromphalus Sowerby, 1848, N.

244 pompilius Linnaeus, 1758, and Allonautilus scrobiculatus Ward \& Saunders, 1997. Shell

245 photographs were accessed via the website Conchology, Inc. (2017). These four taxa are known

246 to sometimes drift postmortem and were therefore classified as having shell forms that are

247 buoyant postmortem.

(2) Shell shape data from Ritterbush \& Bottjer's (2012) ammonoid dataset. In the supplementary materials for their 2012 paper, Ritterbush and Bottjer supplied the scaled and normalized Westermann Morphospace parameters U, Th, and w for 177 ammonoid species.

251 These species represent a broad range of ages, clades, and shell forms. The parameters $U$, Th, 252 and $\mathrm{w}$ are defined formally in the next section, "Westermann Morphospace and postmortem 253 buoyancy".

254 (3) Geographic range and shell shape data for Late Cenomanian and Early Turonian (Late 255 Cretaceous) cephalopods from Yacobucci (2017). Yacobucci (2017) compiled geographic range 256 data for 41 Late Cenomanian and 34 Early Turonian ammonoid genera plus the nautilid genus 257 Eutrephoceras Hyatt, 1894 (which was present in both substages). This dataset therefore offers 258 the opportunity to test whether certain ammonoid shell forms are more likely to show artificially 259 larger geographic ranges due to postmortem drift. Geographic range was estimated as the $\log _{10}$ of 260 the area in square kilometers of a convex hull encompassing all occurrences of each taxon; see 
261 Yacobucci (2017) for further details. To determine the position of these genera in Westermann

262 Morphospace, images of specimens of each genus were located in the ammonoid Treatise

263 volumes (Arkell et al., 1957; Wright, Callomon \& Howarth, 1996) and the nautiloid Treatise

264 volume (Teichert et al., 1964) for Eutrephoceras. These images were used to measure the

265 necessary shell shape characters.

266

(4) Modern nautilid occurrences from Toriyama et al. (1965) and House (1987). House

267 (1987) compiled descriptive locality information and produced a map for occurrences of both

268 living specimens and dead drift shells of modern nautilids, based partly on occurrences reported

269 in Toriyama et al. (1965). Localities were compiled from both sources and species and place

270 names updated as needed. Each location was then georeferenced to the nearest 0.1 decimal

271 degrees latitude and longitude, using Google Earth. In some cases, a single numbered locality

272 was split into multiple locations, as House (1987) lumped together in his locality descriptions

273 places that are actually relatively far apart (e.g., two separate islands within one island chain). A

274 total of 184 separate nautilid occurrences were included in the final dataset.

275 Westermann Morphospace and postmortem buoyancy

276 Five shell shape measurements (a, a', b, D, and UD; Fig. 4) were used to calculate the

277 three parameters defining Westermann Morphospace, following the protocol of Ritterbush \&

278 Bottjer (2012). First, raw values of the three key shape parameters of involution (umbilical ratio

279 U), shell inflation (thickness ratio Th), and whorl expansion rate (w) were calculated:

$280 \quad$ Raw $\mathrm{U}=\mathrm{UD} / \mathrm{D}$

$281 \quad$ Raw $T h=b / D$

$282 \quad$ Raw $w=a / a^{\prime}$ 
283 Next, these three raw parameters were scaled to fall within the range of values for common

284 ammonoids, using the minimum and maximum values provided in Ritterbush and Bottjer (2012, 285 table 2):

Finally, the scaled values were normalized to range from 0 to 1 :

These normalized parameters were used to construct ternary plots of Westermann Morphospace.

294 Each corner of the ternary plot represents the maximum end member value for one of the three shell shape parameters. Individual shell forms plot within the triangular morphospace based on the values of these three parameters. morphology of any normally coiled cephalopods in a reproducible way, unlike sample-specific approaches to visualizing shape variation, such as principal components analysis (PCA), which produces morphospace projections that change depending on the specimens included in the analysis. Occupation patterns within Westermann Morphospace can also be interpreted in terms

302 of mode of life (e.g., nektonic, planktonic, demersal, or vertical migrant), a feature lacking in

303 other morphospace approaches. On the other hand, Westermann Morphospace is based on

304 scaled, normalized parameters, several computational steps removed from the original measurement data. To confirm that the data processing involved in Westermann Morphospace 
306 construction did not affect the general pattern observed, the five measured shell shape characters

307 (a, a', b, D, and UD) were also subjected to principal components analysis (PCA) on their

308 correlation matrix, as well as a multi-group discriminant analysis (canonical variates analysis;

309 CVA) with groups defined as buoyant postmortem, not buoyant postmortem, and intermediate in

310 buoyancy, based on Reyment's (1973) results and normalized shell thickness ratio Th (see

311 Results below, Fig. 5). PCA and CVA were conducted in PAST 3.20 (Hammer, Harper \& Ryan,

312 2001); data sets and detailed results are provided in the Supplementary Material.

313 Analysis of relationship between postmortem buoyancy and geographic range

314 Two approaches were used to assess the prediction that taxa with more buoyant

315 postmortem shell forms would be more likely to drift and therefore have larger geographic

316 ranges. First, the parameter Th was determined to be predictive of whether a taxon was likely to

317 be buoyant or non-buoyant postmortem (see Results below, Fig. 5). Correlations between Th and

318 geographic range were calculated separately for Late Cenomanian and Early Turonian genera

319 and tested for significance (Fig. 6). To check for the influence of taxa with small geographic

320 ranges, which could potentially represent sampling or collecting failures, correlations were

321 calculated for the full datasets and after excluding taxa with smaller ranges $(<1,000 \mathrm{sq} \mathrm{km})$. It

322 should be noted that many of these taxa with small geographic ranges come from well-sampled

323 regions (such as the Western Interior Seaway of North America and the European Platform) and

324 therefore are more likely to reflect truly restricted ranges than sampling bias; in any case, these

325 narrow ranges do not support the notion of extensive postmortem transport. Second, the

326 distributions of geographic ranges for buoyant vs. non-buoyant genera were visualized and

327 Mann-Whitney U-tests used to test for significant differences in the medians of these 
328 distributions (Fig. 7). All statistical tests were conducted in PAST 3.15 (Hammer, Harper \&

329 Ryan, 2001).

330 One complicating factor in assessing the causes of geographic range size is the potential

331 swimming ability of the taxa investigated (Ritterbush et al., 2014). In Ritterbush \& Bottjer's

332 (2012) construction of Westermann Morphospace, they mapped different interpreted modes of

333 life onto their ternary diagram, with good nektonic swimmers represented in the oxyconic

334 portion of the morphospace, vertical migrants with poor horizontal swimming ability in the

335 spherocone region, and planktonic drifters in the serpenticone region. Demersal groups fell in a

336 curved band separating the serpenticone corner from the rest of the morphospace. In order to

337 control for the possible confounding relationship of geographic range size with mode of life,

338 Late Cenomanian and Early Turonian genera were assigned to one of three categories (nektonic,

339 demersal, or vertical migrant) based on their position within Westermann Morphospace. No

340 genera fell within the planktonic region; 19 genera falling near the center of this morphospace

341 were excluded as their mode of life could not be unambiguously assigned. The non-parametric

342 Kruskal-Wallis test was used to determine whether median geographic range was significantly

343 different among modes of life.

344 Geospatial analysis of modern nautilid occurrences

345 ArcGIS 10.3.1 (ESRI, 2015) was used to create maps of modern nautilid occurrences and

346 to calculate convex hulls spanning the occurrences for each species.

347

348 Results

349 Westermann Morphospace 
351 in Westermann morphospace based on their postmortem buoyancy potential (Fig. 5A). The least

352 buoyant taxa (orange circles) and most buoyant taxa (blue circles) mostly fall into separate

353 fields, divided by the line corresponding to a normalized thickness ratio Th (100 x whorl

354 width/shell diameter) of about 30\%. Just two buoyant species fell in the non-buoyant field, and

355 three non-buoyant species fell in the buoyant field. Fourteen of the $17(82 \%)$ ammonoid taxa that

356 Reyment (1973) identified as having an intermediate buoyancy (gray circles) fall in the non-

357 buoyant area. It should be noted that the majority (66\%) of Reyment's ammonoid taxa fall within

358 the non-buoyant area. In contrast, the four living nautilid species (Nautilus belauensis, $N$.

359 macromphalus, N. pompilius, and Allonautilus scrobiculatus; dark blue squares), which are

360 known to experience postmortem transport, plot adjacent to the buoyant ammonoids, but with a 361 higher value of $w$.

362 The majority ( $81 \%$ ) of the 177 ammonoid taxa used in the original Westermann

363 morphospace paper (Ritterbush \& Bottjer, 2012), which represent a broad range of groups and

364 time periods, fall within the non-buoyant field (Fig. 5B, open circles). This result suggests that

365 most ammonoid morphotypes would have had a relatively low potential for postmortem

366 flotation. Only ammonoid taxa with relatively wide, inflated shells would have a high potential

367 for experiencing postmortem transport.

368 Ammonoid genera (plus the nautilid Eutrephoceras) from the Cenomanian-Turonian

369 boundary interval plot in both the non-buoyant and buoyant fields (Fig. 5C, green squares).

370 These results lead to the prediction that genera falling in the buoyant field (that is, with a

371 normalized thickness ratio greater than 30\%) may show artificially inflated geographic range 
372 sizes relative to those contemporaneous taxa with lower postmortem buoyancy, since more

373 buoyant taxa would have been more likely to be transported by surface currents.

374 To confirm that buoyant vs. non-buoyant ammonoids differ in shell form, two other

375 approaches to visualizing morphospace were investigated, PCA and CVA. Detailed results of

376 these analyses are provided in Supplementary Material. These morphospaces also showed good

377 separation of buoyant and non-buoyant shell forms, with buoyant shells falling in the PC or CV

378 space associated with high loadings for whorl breadth $\mathrm{b}$, thereby confirming the pattern observed

379 in Westermann Morphospace.

\section{Relationship between predicted postmortem buoyancy and geographic range}

There is no significant relationship between shell shape and geographic range.

382 Correlations between the normalized thickness ratio and geographic range sizes of Cenomanian-

383 Turonian cephalopods are weak: Early Turonian correlation coefficient $r=0.161(p=0.355)$

384 (Fig. 6A); Late Cenomanian correlation coefficient $r=0.117(\mathrm{p}=0.459)$ (Fig. 6B). Excluding genera with geographic range sizes less than $1,000 \mathrm{sq} \mathrm{km}\left(\log _{10}<3\right)$ did not result in significant correlations (Early Turonian $r=0.399, p=0.073$; Late Cenomanian $r=0.140, p=0.525$ ).

387 Hence, the geographic range size of these cephalopod genera is not predictable based on shell form or the postmortem buoyancy inferred from that form, suggesting that postmortem transport was not an important factor in controlling observed geographic range.

391 for cephalopod shells predicted to be postmortem drifters vs. non-drifters. Genera with shell

392 shapes associated with increased postmortem buoyancy (Fig. 7, blue histograms) do not show

393 larger geographic ranges than less buoyant genera (Fig. 7, orange histograms) in the Late

394 Cenomanian or Early Turonian. Rather, both groups of genera show U-shaped distributions; 
395 numerous genera had small geographic ranges regardless of their postmortem transport potential.

396 Mann-Whitney U-tests reveal no significant differences in the medians of these distributions

397 (Table 1). It seems clear that even if a cephalopod taxon has a shell shape predicted to be more

398 buoyant postmortem, that potential did not in practice result in more postmortem transport and 399 an inflated geographic range.

$400 \quad$ Further, no significant difference in median geographic range was found when grouping

401 these Cenomanian and Turonian ammonoid genera based on their mode of life as predicted by

402 their position in Westermann Morphospace (Table 2). Indeed, the genera with characteristics one

403 might predict would result in larger observed geographic ranges, such as active nektonic

404 swimmers, had smaller median geographic ranges than vertical migrants; perhaps these vertical

405 migrants had less control over their distributions than actively swimming forms.

\section{Modern nautilid geographic distributions}

407 It is interesting to note that Reyment's own buoyancy experiments (Reyment, 1973)

408 showed that fossil cephalopods had a range of postmortem transport potentials, contradicting his

409 persistent claim that most cephalopods experienced extensive transport (Reyment, 2008). The

410 underlying rationale for Reyment's insistence that postmortem drift in shelled cephalopods is the

411 norm was his claim that modern nautilids are known to frequently experience postmortem drift

412 across long distances. This claim is based on observed occurrences of living nautilid specimens

413 and beached shells interpreted as having drifted away from living populations as reported in

414 Toriyama et al. (1965) and House (1987). As noted in the Introduction, while drift has been

415 observed, actual evidence for long-distance transport of nautilid shells is actually relatively rare

416 (Wani et al., 2005). 
418 northern Australia, New Guinea, Indonesia, Palau, and the Philippines (Fig. 8A, orange circles).

419 Drift shells, on the other hand, have been found over a much wider area, including further north

420 in the Pacific, around southern Australia, and across the Indian Ocean (Fig. 8A, brown circles).

421 Pooling all nautilid species together makes it appear that nautilids are prone to extensive

422 postmortem transport.

However, investigating the geospatial distributions of individual nautilid species reveals a

424 more complex pattern. Four of the five generally recognized nautilid (morpho)species $(N$.

425 belauensis, N. macromphalus, N. stenomphalus Sowerby, 1848, and Allonautilus scrobiculatus;

426 Barord et al., 2014) have relatively small living geographic ranges (Fig. 8B, Table 3). Drift shells

427 of these species (darker circles) are rare and remain relatively close to the living population from

428 which they are derived. For example, the one reported location of drifted N. stenomphalus falls

429 within the known living range of the species. $N$. belauensis is known only from Palau, while drift

430 shells have been recovered about 1,100 km away in Mindanao, Philippines (House, 1987). $N$.

431 macromphalus lives in the area of New Caledonia, while drift shells have been found 2,100 km

432 away in southeast Australia (House, 1987). While these distances are not trivial, they also do not 433 extend the known range of these species to new ocean basins.

434 The exception to this pattern is $N$. pompilius, which has a much larger living range than

435 the other nautilid species as well as drifted shells observed across a large part of the Indo-Pacific

436 (Table 3, Fig. 8B, green circles). House (1987) and Reyment (2008) claimed that drifted shells in

437 the western Indian Ocean must have derived from living populations in the Philippines, implying

438 travel of dead shells over distances of over 9,000 km. It is not clear, however, why N. pompilius

439 would be so much more capable of long-distance postmortem transport compared to the other 
440 living nautilid species, which are quite similar in their habitats, shell forms, and postmortem

441 buoyancy and which can co-occur with $N$. pompilius and therefore experience the same

442 oceanographic conditions and currents (Saunders, 1987; Saunders \& Ward, 1987).

443

444 Discussion

445 Postmortem drift in fossil cephalopods

The results presented here support the claim that the majority of ammonoid taxa

447 (including both Paleozoic and Mesozoic groups) would have been considerably less likely to

448 experience postmortem transport than modern nautilids. Only the subset of ammonoid taxa with

449 relatively inflated shells would experience sufficient postmortem buoyancy to float for any

450 length of time, a prerequisite for extensive transport away from their living habitat. Further, this

451 conclusion does not consider that other factors, such as the depth at which the animal died, could

452 further diminish the likelihood of postmortem drift, as animals in deeper water are more likely to

453 become waterlogged and sink more quickly (Chamberlain, Ward \& Weaver, 1981; Maeda \&

454 Seilacher, 1996). Based on evidence from Late Cretaceous ammonoids, genera with shell forms

455 conducive to postmortem floating did not have larger geographic ranges (Fig. 6), indicating that

456 even those fossil cephalopods with a greater chance of postmortem transport did not likely

457 actually experience extensive movement away from their living habitat. It should be noted that

458 such shell forms are associated with a vertical migrant life mode (Ritterbush \& Bottjer, 2012).

459 The lack of significantly larger geographic ranges in such taxa indicates that neither transport

460 during life nor postmortem drift markedly increased their observed geographic distributions.

461 These results are consistent with previous workers' arguments for the rarity of extensive

462 postmortem transport of fossil cephalopods, based on taphonomic evidence (Kennedy \& Cobban, 
463 1976; Hewitt, 1988; Maeda \& Seilacher, 1996; Maeda et al., 2003; Wani, 2004; Wani et al.,

464 2005; Mapes et al., 2010a; Lukeneder, 2015) and buoyancy considerations (Chamberlain, Ward

465 \& Weaver, 1981; Hewitt \& Westermann, 1996; Chirat, 2000; Wani \& Gupta, 2015). They also

466 provide a measure of confidence that fossil locality data are a robust proxy for living

467 biogeographic ranges.

468 Implications for modern nautilid distributions

The notion that postmortem transport was common in fossil cephalopods ultimately

derives from the claim that modern nautilids show frequent and extensive postmortem drift.

471 However, drifted nautilid shells are actually fairly rare (Wani et al., 2005) and only one extant

472 nautilid species, $N$. pompilius, shows widely distributed drift shells. The limited geographic

473 distributions of most nautilid species are consistent with evidence for genetic divergence of

474 geographically separated populations (Wray et al., 1995; Bonnaud, Ozouf-Costaz \& Boucher-

475 Rodoni, 2004; Sinclair et al., 2007, 2011; Bonacum et al., 2011; Williams et al., 2015; Vandepas

476 et al., 2016). The wider distribution of $N$. pompilius may be real or the result of pooling multiple

477 genetically distinct populations into single named species. N. pompilius does appear to contain

478 more genetic variation than other nautilid species, and may be paraphyletic, with $N$.

479

stenomphalus and N. belauensis falling within N. pompilius sensu latu (Bonacum et al., 2011;

480 Vandepas et al., 2016; Combosch et al., 2017 Saunders, Greenfest-Allen \& Ward, 2017). Hence,

481 the wide distribution of $N$. pompilius drift shells could actually be caused by the conflation of

482 smaller drift ranges of separate populations.

483 The abundance of drifted N. pompilius shells in the western Indian Ocean is particularly

484 remarkable, as these sites are quite distant from known living populations (Fig. 8B). Both House

485 (1987) and Reyment (2008) argued that the $N$. pompilius shells that wash up in some numbers on 
486 beaches in Kenya and Mozambique must have drifted across the entire Indian Ocean from living

487 populations in the Philippines. Under this view, floating shells would need to move from the

488 Philippines into the eastern Indian Ocean basin, where they could then be picked up by the

489 westward flowing North or South Equatorial surface currents. This mechanism could

490 conceivably bring floating shells across the Indian Ocean to Africa, but would require the shells

491 to remain relatively undamaged (so as to continue floating) for a journey of over $6,000 \mathrm{~km}$ and to

492 avoid being caught up in the eastward flowing Equatorial Countercurrent or the Indian Ocean

493 gyre lying south of the equatorial currents (National Weather Service, 2018). In addition to these

494 obstacles, it is difficult to understand why this one species of nautilid would show such different

495 postmortem behavior than its close relatives. As an alternative, it might be possible that these

496 African drift shells are actually being sourced from living populations much closer, in the

497 western Indian Ocean basin (House, 1973; Wani et al., 2005; Matteucci, 2015). Live Nautilus

498 (presumed to be N. pompilius) have been reported from Madagascar (Teichert, 1970) and from

499 Mauritius and the Seychelles (by Dr. Anna Bidder, cited in Reyment (1973)), and late

500 Pleistocene fossils of Nautilus (likely N. pompilius) have been identified on the Bajuni Islands

501 off the Somali coast (Matteucci, 2015). The distances from the isolated islands of the western

502 Indian Ocean to the African mainland are more consistent with the distances traveled by dead

503 shells of the other nautilid species. The possibility of living $N$. pompilius populations within the

504 western Indian Ocean basin is therefore worthy of further investigation, especially in light of

505 new conservation efforts for this iconic marine animal. In addition to a search for living

506 populations in the waters surrounding Madagascar, Mauritius, the Comoros, the Seychelles, and

507 in reef settings off the East African coast, further investigation of potential nautilid fossils from

508 late Pleistocene deposits, like those described by Matteucci (2015) from Somalia, is warranted. 
509 Recovered drift shells of nautilids from East Africa should also be assessed for age (for instance,

510 by radiocarbon or amino acid racemization techniques; Tomašových et al., 2017) and possible

511 sequenceable organic material, which would allow the placement of these shells in the larger

512 phylogenetic context of nautilids throughout the Indo-Pacific region.

513 Such new discoveries are not without precedent. A second species of coelacanth,

514 Latimeria menadoensis Pouyaud, Wirjoatmodjo, Rachmatika, Tjakrawidjaja, Hadiaty \& Hadie

515 1999, was identified in Indonesia in 1997, nearly 10,000 km east across the Indian Ocean from

516 the coelacanths' known range in east Africa (Pouyaud et al., 1999). Genetic data suggest these

517 two species have been separated for tens of million years (Holder et al., 1999; Inoue et al., 2005).

518 It seems clear that the marine biota of the Indian Ocean, especially deeper water species like the

519 nautilus and the coelacanth, is still incompletely known.

520

521 Conclusions

While postmortem transport of cephalopod shells in modern and fossil contexts is

523 frequently assumed to have been both frequent and extensive, evidence supporting this view is

524 lacking. Most fossil ammonoids had shell forms that resulted in low postmortem buoyancy; only

525 highly inflated shells were likely to float for significant periods after death. An analysis of early

526 Late Cretaceous (Cenomanian-Turonian) cephalopod genera shows that observed geographic

527 range size was not related to likelihood of postmortem transport, indicating that these observed

528 fossil ranges are adequate proxies for living geographic ranges. Most living nautilid species have

529 relatively small geographic ranges with limited dispersal of drift shells. The exception, Nautilus

530 pompilius, is widespread throughout the Indo-Pacific, with drift shells found apparently great

531 distances from known living populations. However, drift shells found along the east African 
532 coast may in reality be derived from cryptic living populations among the isolated islands of the

533 western Indian Ocean.

534

535 Acknowledgements

536 The author would like to thank R. Hoffmann, N. Landman, B. Linzmeier, R. Mapes, and K.

537 Ritterbush for helpful discussions, and A. Avruch, K. De Baets, R. Wani, R. Lemanis, and an

538 anonymous review for very constructive reviews of the manuscript. This paper is dedicated to

539 the memory of Richard Reyment, who passed away in 2016; his pioneering combination of

540 experimental and quantitative analyses of ammonoid form and function have made work like this

541 possible.

542

\section{References}

544 Arkell WJ, Furnish WM, Kummel B, Miller AK, Moore RC, Schindewolf OH, Sylvester-

545 Bradley PC, Wright CW. 1957. Treatise on Invertebrate Paleontology, Part L, Mollusca 4.

546 Cephalopoda, Ammonoidea. Boulder, Colorado and Lawrence, Kansas: Geological Society

547 of America and University of Kansas.

548 Barord GJ, Dooley F, Dunstan A, Ilano A, Keister KN, Neumeister H, Preuss T, Schoepfer S,

549 Ward PD. 2014. Comparative population assessments of Nautilus sp. in the Philippines,

550 Australia, Fiji, and American Samoa using baited remote underwater video systems. PLoS

551 ONE 9(6): e100799. DOI: 10.1371/journal.pone.0100799.

552 Bonacum J, Landman NH, Mapes RH, White MM, White A-J, Irlam J. 2011. Evolutionary

553 radiation of present-day Nautilus and Allonautilus. American Malacological Bulletin 29:77-

554 93. DOI: $10.4003 / 006.029 .0221$. 
555 Bonnaud L, Ozouf-Costaz C, Boucher-Rodoni R. 2004. A molecular and karyological approach

556 to the taxonomy of Nautilus. Comptes Rendus Biologies 327:133-138. DOI:

$557 \quad$ 10.1016/j.crvi.2003.12.004.

558 Brayard A, Escarguel G, Bucher H. 2007. The biogeography of Early Triassic ammonoid faunas:

559 Clusters, gradients, and networks. Geobios 40:749-765. DOI: 0.1016/j.geobios.2007.06.002.

560 Brayard A, Escarguel G, Monnet C, Jenks JF, Bucher H. 2015. Biogeography of Triassic

561 ammonoids. In: Klug C, Korn D, De Baets K, Kruta I, Mapes RH, eds. Ammonoid

562 paleobiology: from macroevolution to paleogeography. Topics in Geobiology 44:163-187.

563 Dordrecht: Springer. DOI: 10.1007/978-94-017-9633-0_7.

564 Bronn HG. 1838. Lethaea Geognostica oder Abbildungen und Beschreibungen der für die

565 Gebirge-Formationen bezeichnendsten Versteinerungen 2:545-1346.

566 Buch L v. 1850. Über Ceratiten. Abhandlungen der Königlich Preussischen Akademie der

567 Wissenschaften zu Berlin. physikalische Klasse, 1-43, Taf. 1-7, Berlin.

568 Cecca F. 2002. Palaeobiogeography of marine fossil invertebrates: concepts and methods.

569 London: Taylor and Francis.

570 Chamberlain JA Jr, Ward PD, Weaver JS. 1981. Post-mortem ascent of Nautilus shells:

571 implications for cephalopod paleobiogeography. Paleobiology 7:494-509. DOI:

$572 \quad 10.1017 / \mathrm{S} 0094837300025549$.

573 Chamberlain JA Jr, Weaver JS. 1978. Equations of motion for post-mortem sinking of

574 cephalopod shells. Mathematical Geology 10:673-689. DOI: 10.1007/BF01031898

575 Chirat R. 2000. The so-called 'cosmopolitan palaeobiogeographic distribution' of Tertiary

$576 \quad$ Nautilida of the genus Aturia Bronn 1838: the result of post-mortem transport by oceanic 
577

578

579

580

581

582

583

584

585

586

587

588

589

590

591

592

593

594

595

596

597

598

599

palaeocurrents. Palaeogeography, Palaeoclimatology, Palaeoecology 157:59-77. DOI: 10.1016/S0031-0182(99)00150-9.

Clements T, Colleary C, De Baets K, Vinther J. 2017. Buoyancy mechanisms limit preservation of coleoid cephalopod soft tissues in Mesozoic Lagerstätten. Palaeontology 60:1-14. DOI: 10.1111/pala.12267.

Combosch DJ, Lemer S, Ward PD, Landman NH, Giribet G. 2017. Genomic signatures of evolution in Nautilus - An endangered living fossil. Molecular Ecology 26:5923-5938. DOI: 10.1111/mec. 14344 .

Conchology, Inc. 2017. Available at https://www.conchology.be (accessed 22 June 2017).

De Angelis P. 2012. Assessing the impact of international trade on chambered nautilus. Geobios 45:5-11. DOI: 10.1016/j.geobios.2011.11.005.

Denton EJ, Gilpin-Brown JB. 1966. On the buoyancy of the pearly nautilus. Journal of the Marine Biological Association of the U.K. 46:723-759. DOI: 10.1017/S0025315400033440.

Dera G, Neige P, Dommergues J-L, Brayard A. 2011. Ammonite paleobiogeography during the Pliensbachian-Toarcian crisis (Early Jurassic) reflecting paleoclimate, eustasy, and extinctions. Global and Planetary Change 78:92-105. DOI:

10.1016/j.gloplacha.2011.05.009.

Dunstan A, Alanis O, Marshall J. 2010. Nautilus pompilius fishing and population decline in the Philippines: a comparison with an unexploited Australian Nautilus population. Fisheries Research 106:239-247. DOI: 10.1016/j.fishres.2010.06.015.

Dunstan A, Bradshaw CJA, Marshall J. 2011. Nautilus at risk-estimating population size and demography of Nautilus pompilius. PLoS One 6(2):e16716. DOI: 10.1371/journal.pone.0016716. 
600 Dunstan AJ, Ward PD, Marshall NJ. 2011a. Nautilus pompilius life history and demographics at 601 the Osprey Reef Seamount, Coral Sea, Australia. PLoS One 6(2):e16312. DOI:

602 10.1371/journal.pone.0016312.

603 Dunstan AJ, Ward PD, Marshall NJ. 2011b. Vertical distribution and migration patterns of 604 Nautilus pompilius. PLoS One 6(2):e16311. DOI: 10.1371/journal.pone.0016311.

605 ESRI (Environmental Systems Research Institute). 2015. ArcGIS Desktop, Release 10.3.1. 606 Redlands, California: ESRI.

607 ESRI (Environmental Systems Research Institute). 2016. Ocean Basemap. Available at 608 https://www.arcgis.com/home/item.html?id=5ae9e138a17842688b0b79283a4353f6 609 (accessed 15 September 2017).

610 Greenwald L, Ward PD. 1987. Buoyancy in Nautilus. In: Saunders WB, Landman NH, eds. 611 Nautilus: the biology and paleobiology of a living fossil. Topics in Geobiology 6:547-560. $612 \quad$ New York: Plenum Press.

613 Hamada T. 1964. Notes on drifted Nautilus in Thailand. Scientific Papers of the College of 614 General Education, University of Tokyo 14:255-277.

615 Hammer $\varnothing$, Bucher H. 2006. Generalized ammonoid hydrostatics modelling, with application to 616 Intornites and intraspecific variation in Amaltheus. Paleontological Research 10:91-96. DOI: $617 \quad 10.2517 /$ prpsj.10.91.

618 Hammer Ø, Harper DAT, Ryan PD. 2001. PAST: Paleontological statistics software package for 619 education and data analysis. Palaeontologia Electronica 4(1):article 4.

620 Hembree DI, Mapes RH, Goiran C. 2014. The impact of high-energy storms on shallow-water 621 Nautilus (Cephalopoda) taphonomy, Lifou (Loyalty Islands). Palaios 29:348-362. DOI: $622 \quad 10.2110 /$ palo.2013.113. 
623 Hewitt RA. 1988. Nautiloid shell taphonomy: interpretations based on water pressure.

624 Palaeogeography, Palaeoclimatology, Palaeoecology 63:15-25. DOI: 10.1016/0031-

$625 \quad 0182(88) 90088-0$.

626 Hewitt RA, Westermann GEG. 1996. Post-mortem behaviour of Early Paleozoic nautiloids and 627 paleobathymetry. Paläontologische Zeitschrift 70:405-424. DOI: 10.1007/BF02988081.

628 Hoffmann R, Lemanis R, Naglik C, Klug C. 2015. Ammonoid buoyancy. In: Klug C, Korn D, 629 De Baets K, Kruta I, Mapes RH, eds. Ammonoid paleobiology: from anatomy to ecology. 630 Topics in Geobiology 43:613-648. Dordrecht: Springer. DOI: 10.1007/978-94-017-96306319 9_16.

632 Hoffmann R, Zachow S. 2011. Non-invasive approach to shed new light on the buoyancy 633 business of chambered cephalopods. IAMG 2011 Publication. DOI: $634 \quad$ 10.5242/iamg.2011.0163.

635 Holder MT, Erdmann MV, Wilcox TP, Caldwell RL, Hillis DM. 1999. Two living species of 636 coelacanths? Proceedings of the National Academy, U.S.A. 96:12616-12620.

637 House MR. 1973. An analysis of Devonian goniatite distributions. In: Hughes NF, eds.

638 Organisms and continents through time. Special Papers in Palaeontology 12:305-317.

639 House MR. 1987. Geographic distribution of Nautilus shells. In: Saunders WB, Landman NH, 640 eds. Nautilus: the biology and paleobiology of a living fossil. Topics in Geobiology 6:53-64. 641 New York: Plenum Press.

642 Hyatt A. 1894. Phylogeny of an acquired characteristic. Proceedings of the American 643 Philosophical Society 32(143):349-647.

644 Ifrim C, Lehmann J, Ward P. 2015. Paleobiogeography of Late Cretaceous ammonoids. In: Klug 645 C, Korn D, De Baets K, Kruta I, Mapes RH, eds. Ammonoid paleobiology: from 
646

647

648

649

650

651

652

653

654

655

656

657

658

659

660

661

662

663

664

665 Baets K, Kruta I, Mapes RH, eds. Ammonoid paleobiology: from macroevolution to 666 paleogeography. Topics in Geobiology 44:145-161. Dordrecht: Springer. DOI: 10.1007/978667 94-017-9633-0_6.

macroevolution to paleogeography. Topics in Geobiology 44:259-274. Dordrecht: Springer. DOI: 10.1007/978-94-017-9633-0_10.

Inoue JG, Miya M, Venkatesh B, Nishida M. 2005. The mitochondrial genome of Indonesian coelacanth Latimeria menadoensis (Sarcopterygii: Coelacanthiformes) and divergence time estimation between the two coelacanths. Gene 349:227-235. DOI:

$$
\text { 10.1016/j.gen.2005.01.008. }
$$

Iredale T. 1944. Australian pearly Nautilus. Australian Zoologist 10:294-298.

Jacobs DK, Chamberlain JA Jr. 1996. Buoyancy and hydrodynamics in ammonoids. In:

Landman NH, Tanabe K, Davis RA, eds. Ammonoid paleobiology. Topics in Geobiology 13. Plenum, New York.

Kennedy WJ, Cobban WA. 1976. Aspects of ammonite biology, biogeography, and biostratigraphy. Special Papers in Palaeontology 17. London: Palaeontological Association.

Kidwell SM, Flessa KW. 1996. The quality of the fossil record: Populations, species, and communities. Annual Review of Earth and Planetary Sciences 24:433-464. DOI: 10.1146/annurev.earth.24.1.433.

Kobayashi T. 1954. A contribution towards Palaeo-Flumenology, science of the oceanic currents of the past, with a description of a new Miocene Aturia from central Japan. Japanese Journal of Geology and Geography 25:35-56.

Korn D, De Baets K. 2015. Biogeography of Paleozoic ammonoids. In: Klug C, Korn D, De 
668 Kröger B. 2002. On the efficiency of the buoyancy apparatus in ammonoids: evidences from 669 sublethal shell injuries. Lethaia 35:61-70. DOI: 10.1111/j.1502-3931.2002.tb00068.x.

670 Lehmann J, Ifrim C, Bulot L, Frau C. 2015. Paleobiogeography of Early Cretaceous ammonoids.

671 In: Klug C, Korn D, De Baets K, Kruta I, Mapes RH, eds. Ammonoid paleobiology: from 672 macroevolution to paleogeography. Topics in Geobiology 44:229-257. Dordrecht: Springer. 673 DOI: 10.1007/978-94-017-9633-0_9.

674 Lemanis R, Zachow S, Fusseis F, Hoffmann R. 2015. A new approach using high-resolution 675 computed tomography to test the buoyant properties of chambered cephalopod shells. 676 Paleobiology 41:313-329. DOI: 10.1017/pab.2014.17.

677 Linnaeus C. 1758. Systema Naturae, 10th edition. Stockholm: Holmiae.

678 Luci L, Cichowolski M. 2014. Encrustation in nautilids: A case study in the Cretaceous species 679 Cymatoceras perstriatum, Neuquén Basin, Argentina. Palaios 29:101-120. DOI: $680 \quad 10.2110 /$ palo.2013.062.

681 Luci L, Cichowolski M, Aguirre-Urreta MB. 2016. Sclerobionts, shell morphology and 682 biostratinomy on ammonites: Two Early Cretaceous cases from the Neuquén Basin, 683 Argentina. Palaios 31:41-54. DOI: 10.2110/palo.2015.052.

684 Lukeneder A. 2015. Ammonoid habitats and life history. In: Klug C, Korn D, De Baets K, Kruta 685 I, Mapes RH, eds. Ammonoid paleobiology: from anatomy to ecology. Topics in Geobiology 686 43:689-791. Dordrecht: Springer. DOI: 10.1007/978-94-017-9630-9_18.

687 Maeda H., Seilacher A. 1996. Ammonoid taphonomy. In: Landman NH, Tanabe K, Davis, RA, 688 eds. Ammonoid paleobiology. Topics in Geobiology 13:543-578. New York: Plenum Press. 
689 Maeda H, Mapes RH, Mapes G. 2003. Taphonomic features of a Lower Permian beached 690 cephalopod assemblage from Central Texas. Palaios 18:421-434. DOI: 10.1669/0883$691 \quad 1351(2003) 018<0421:$ TFOALP $>2.0$. CO;2.

692 Mapes RH, Landman NH, Cochran K, Goiran C, Richer de Forges B, Renfro A. 2010a. Early 693 taphonomy and significance of naturally submerged Nautilus shells from the New Caledonia 694 region. Palaios 25:597-610. DOI: 10.2110/palo.2009.p09-109r.

695 Mapes RH, Hembree DI, Rasor BA, Stigall A, Goiran C, Richer de Forges B. 2010b. Modern 696 Nautilus (Cephalopoda) taphonomy in a subtidal to backshore environment, Lifou (Loyalty 697 Islands). Palaios 25:656-670. DOI: 10.2110/palo.2010.p10-010r.

698 Matteucci R. 2015. Drifted Nautilus shells from the Bajuni Islands (southern Somali coast of 699 Indian Ocean). Journal of Mediterranean Earth Sciences 7:35-50. DOI: 3304/JMES.2015.004.

701

Naglik C, Rikhtegar F, Klug C. 2014. Buoyancy of some Palaeozoic ammonoids and their 702 hydrostatic properties based on empirical 3D-models. Lethaia 49:3-12. DOI:

Naglik C, Tajika A, Chamberlain J, Klug C. 2015. Ammonoid locomotion. In: Klug C, Korn D,

705 De Baets K, Kruta I, Mapes RH, eds. Ammonoid paleobiology: from anatomy to ecology.

706 Topics in Geobiology 43:649-688. Dordrecht: Springer. DOI: 10.1007/978-94-017-96307079 9_17.

708 National Weather Service. 2018. JetStream Max: Major Ocean Currents. Available at 709 https://www.weather.gov/jetstream/currents_max (accessed 6 Oct 2018).

710 Peterman D, Barton CC, Yacobucci MM. In revision, 2018. The hydrostatics of Paleozoic 711 ectocochleate cephalopods (Nautiloidea and Endoceratoidea) with implications for modes of 
712 life and early colonization of the pelagic zone. Submitted to Palaeontologia Electronica,

713 reviewed, and currently in revision for resubmission.

714 Philippi E. 1901. Die Ceratiten des oberen deutschen Muschelkalkes. Palaeontologische

715 Abhandlungen 8, Neue Folge 4:347-457.

716 Pouyaud L, Wirjoatmodjo S, Rachmatika I, Tjakrawidjaja A, Hadiaty R, Hadie W. 1999. Une

717 nouvelle espèce de coelacanthe. Preuves génétiques et morphologiques. Comptes Rendus de

718 l'Académie des Sciences, Series III, Sciences de la Vie 322:261-267.

719 Reid A. 2016. Post-mortem drift in Australian cuttlefish sepions: its effect on the interpretation

720 of species ranges. Molluscan Research 36:9-21. DOI: 10.1080/13235818.2015.1064366.

721 Reyment RA. 1958. Some factors in the distribution of fossil cephalopods. Stockholm

722 Contributions in Geology 1:97-184+ 7 plates.

723 Reyment RA. 1970. Vertically inbedded cephalopod shells. Some factors in the distribution of

724 fossil cephalopods, 2. Palaeogeography, Palaeoclimatology, Palaeoecology 7:103-111.

725 DOIL 10.1016/0031-0182(70)90071-4.

726 Reyment RA. 1973. Factors in the distribution of fossil cephalopods. Part 3: Experiments with

727 exact models of certain shell types. Bulletin of the Geological Institutions of the University of

$728 \quad$ Uppsala, N.S. 4:7-41.

729 Reyment RA. 2008. A review of the post-mortem dispersal of cephalopod shells. Palaeontologia

730 Electronica 11:12A.

731 Ritterbush KA, Bottjer DJ. 2012. Westermann Morphospace displays ammonoid shell shape and

732 hypothetical paleoecology. Paleobiology 38:424-446. DOI: 10.1666/10027.1. 
733 Ritterbush KA, Hoffmann R, Lukeneder A, De Baets K. 2014. Pelagic palaeoecology: the

734 importance of recent constraints on ammonoid palaeobiology and life history. Journal of

735 Zoology 292:229-241. DOI: 10.1111/jzo.12118.

736 Rojas A, Patarroyo P, Mao L, Bengtson P, Kowalewski M. 2017. Global biogeography of Albian

737 ammonoids: A network-based approach. Geology 45:659-662. DOI: 10.1130/G38944.1.

738 Roux M. 1990. Underwater observations of Nautilus macromphalus off New Caledonia.

739 Chambered Nautilus Newsletter 60:1.

740 Roux M, Bouchet P, Bourseau JP, Gaillard C, Grandperrin R, Guille A, Laurin B, Monniot C,

741 Richer de Forges B, Rio M, Segonzac M, Vacelet J, Zibrowius H. 1991. L'environnement

742 bathyal au large de la Nouvelle-Calédonie: Résultats préliminaires de la campagne CALSUB

743 et conséquences paléoécologiques. Bulletin, Société Géologique de France 162:675-685.

744 Saunders WB. 1981. A new species of Nautilus from Palau. Veliger 24:1-7.

745 Saunders WB. 1987. The species of Nautilus. In: Saunders WB, Landman NH, eds. Nautilus: the

746 biology and paleobiology of a living fossil. Topics in Geobiology 6:35-52. New York:

747 Plenum Press.

748 Saunders WB, Ward PD. 1987. Ecology, distribution, and population characteristics of Nautilus.

749 In: Saunders WB, Landman NH, eds. Nautilus: the biology and paleobiology of a living

750 fossil. Topics in Geobiology 6:137-162. New York: Plenum Press.

751 Saunders WB, Greenfest-Allen E, Ward PD. 2017. Demographic disequilibrium in living

752 nautiloids (Nautilus and Allonautilus): Canary in the coal mines? PLoS ONE

753 12(7):e0179811. DOI: 10.1371/journal.pone.0179811. 
754 Seuss B, Hembree DI, Wisshak M, Mapes RH, Landman NH. 2015. Taphonomy of backshore

755 versus deep-marine collected Nautilus macromphalus conchs (New Caledonia). Palaios

756 30:503-513. DOI: 10.2110/palo.2014.057.

757 Sinclair W, Briskey L, Aspden W, Pegg GG. 2007. Genetic diversity of isolated populations of

$758 \quad$ Nautilus pompilius in the Coral Sea. Reviews in Fish Biology and Fisheries 17:223-235.

759 DOI: $10.1007 / \mathrm{s} 11160-006-9030-\mathrm{x}$.

760 Sinclair W, Newman SJ, Vianna GS, Williams S, Aspden WJ. 2011. Spatial subdivision and

761 generic diversity in populations on the east and west coasts of Australia: the multi-faceted

762 case of Nautilus pompilius (Mollusca, Cephalopoda). Reviews in Fisheries Science 19:52-61.

763 DOI: $10.1080 / 10641262.2010 .533794$.

764 Sowerby GB. 1848. Monograph of the genus Nautilus. Thesaurus Conchyliorum 2:463-465.

765 Stenzel HB. 1964. Living Nautilus. Pp. K59-K93 in: Moore RC, ed. Treatise on Invertebrate

766 Paleontology, Part K, Mollusca 3. Cephalopoda-General Features-Endoceratoidea-

767 Actinoceratoidea-Nautiloidea-Bactritoidea. Boulder, Colorado and Lawrence, Kansas:

768 Geological Society of America and University of Kansas.

769 Tajika A, Naglik C, Morimoto N, Pascual-Cebrian E, Hennhöfer DK, Klug C. 2014. Empirical

770 3D-model of the conch of the Middle Jurassic ammonite microconch Normannites, its

771 buoyancy, the physical effects of its mature modifications and speculations on their function.

772 Historical Biology 27:181-191. DOI: 10.1080/08912963.2013.872097.

773 Tanabe K. 1979. Palaeoecological analysis of ammonoid assemblages in the Turonian Scaphites

774 facies of Hokkaido, Japan. Palaeontology 22:609-630.

775 Teichert C. 1970. Drifted Nautilus shells in the Bay of Bengal. Journal of Paleontology 44:1129-

$776 \quad 1145$. 
777 Teichert C, Kummel B, Sweet WC, Stenzel HB, Furnish WM, Glenister BF, Erben HK, Moore

778 RC, Nodine Zeller DE. 1964. Treatise on Invertebrate Paleontology, Part K, Mollusca 3.

779 Cephalopoda-General Features-Endoceratoidea-Actinoceratoidea-Nautiloidea-Bactritoidea.

780 Boulder, Colorado and Lawrence, Kansas: Geological Society of America and University of

$781 \quad$ Kansas.

782 Tomašových A, Kidwell SM. 2009. Fidelity of variation in species composition and diversity

783 partitioning by death assemblages: time-averaging transfers diversity from beta to alpha

784 levels. Paleobiology 35:94-118. DOI: 10.1666/08024.1.

785 Tomašových A, Schlögl J, Kaufman DS, Hudáčková N. 2016. Temporal and bathymetric

786 resolution of nautiloid death assemblages in stratigraphically condensed oozes (New

787 Caledonia). Terra Nova 28:271-278. DOI: 10.1111/ter.12218.

788 Tomašových A, Schlögl J, Biroň A, Hudáčková N, Mikuš T. 2017. Taphonomic clock and

789 bathymetric dependence of cephalopod preservation in bathyal, sediment-starved

790 environments. Palaios 32:135-152. DOI: 10.2110/palo.2016.039.

791 Toriyama R, Sato T, Hamada T, Komalarjun P. 1965. Nautilus pompilius drifts on the west coast

792 of Thailand. Japanese Journal of Geology and Geography 36:149-161.

793 Trueman AE. 1941. The ammonite body chamber with special reference to the buoyancy and

794 mode of life of the living ammonite. Quarterly Journal of the Geological Society of London

$795 \quad 96: 339-383$

796 Tyler CL, Kowalewski M. 2017. Surrogate taxa and fossils as reliable proxies of spatial

797 biodiversity patterns in marine benthic communities. Proceedings of the Royal Society B

$798 \quad 284: 20162839$. DOI: $10.1098 /$ rspb.2016.2839. 
799 Vandepas LE, Dooley FD, Barord GJ, Swalla BJ, Ward PD. 2016. A revisited phylogeography

800 of Nautilus pompilius. Ecology and Evolution 6:4924-4935. DOI: 10.1002/ece3.2248.

801 Walther J. 1897. Über die Lebensweise fossiler Meeresthiere. Zeitschrift der deutschen

802 geologischen Gesellschaft 49(2):209-273.

803 Wani R. 2004. Experimental fragmentation patterns of modern Nautilus shells and the

804 implications for fossil cephalopod taphonomy. Lethaia 37:113-123. DOI:

$805 \quad 10.1080 / 00241160410006420$.

806 Wani R. 2017. Geological duration of ammonoids controlled their geographical range of fossil 807 distribution. PeerJ 5:e4108. DOI: 10.7717/peerj.4108.

808 Wani R, Gupta NS. 2015. Ammonoid taphonomy. In: Klug C, Korn D, De Baets K, Kruta I,

809 Mapes RH, eds. Ammonoid paleobiology: from macroevolution to paleogeography. Topics in

810 Geobiology 44:555-598. Dordrecht: Springer. DOI: 10.1007/978-94-017-9633-0_20.

811 Wani R, Kase T, Shigeta Y, De Ocampo R. 2005. New look at ammonoid taphonomy, based on

812 field experiments with modern chambered nautilus. Geology 33:849-852. DOI:

$813 \quad 10.1131 / \mathrm{G} 21712.1$

814 Ward PD, Greenwald L. 1982. Chamber refilling in Nautilus. Journal of the Marine Biological

$815 \quad$ Association of the U.K. 62:469-475. DOI: 10.1017/S0025315400057404.

816 Ward PD, Martin AW. 1978. On the buoyancy of the pearly Nautilus. Journal of Experimental 817 Zoology 205:5-12. DOI: 10.1002/jez.1402050103.

818 Ward PD, Saunders WB. 1997. Allonautilus: a new genus of living nautiloid cephalopod and its

819 bearing on phylogeny of the Nautilida. Journal of Paleontology 71:1054-1064. DOI:

$820 \quad 10.1017 / \mathrm{S} 0022336000036039$. 
821 Ward P, Dooley F, Barord GJ. 2016. Nautilus: biology, systematics, and paleobiology as viewed

822 from 2015. Swiss Journal of Palaeontology 135:169-185. DOI: s13358-016-0112-7.

823 Westermann GEG. 1971. Form, structure and function of shell and siphuncle in coiled Mesozoic

824 ammonoids. Life Science Contributions, Royal Ontario Museum 78:1-39

825 Williams RC, Jackson BC, Duvaux L, Dawson DA, Burke T, Sinclair W. 2015. The genetic

826 structure of Nautilus pompilius populations surrounding Australia and the Philippines.

827 Molecular Ecology 24:3316-3328. DOI: 10.1111/mec.13255.

828 Wray CG, Landman NH, Saunders WB, Bonacum J. 1995. Genetic divergence and geographic

829 diversification in Nautilus. Paleobiology 21:220-228. DOI: 10.1017/S009483730001321X.

830 Wright CW, with Callomon JH, Howarth MK. 1996. Treatise on Invertebrate Paleontology, Part

831 L, Mollusca 4, Revised. Volume 4: Cretaceous Ammonoidea. Boulder, Colorado and

832 Lawrence, Kansas: Geological Society of America and University of Kansas.

833 Yacobucci MM. 2015. Macroevolution and paleobiogeography of Jurassic-Cretaceous

834 ammonoids. In: Klug C, Korn D, De Baets K, Kruta I, Mapes RH, eds. Ammonoid

835 paleobiology: from macroevolution to paleogeography. Topics in Geobiology 44:189-228.

836 Dordrecht: Springer. DOI: 10.1007/978-94-017-9633-0_8.

837 Yacobucci MM. 2017. Marine life in a greenhouse world: cephalopod biodiversity and

838 biogeography during the early Late Cretaceous. Paleobiology 43:587-619. DOI:

$839 \quad 10.1017 /$ pab.2017.3.

840 Zacaï A, Brayard A, Dommergues J-L, Meister C, Escarguel G, Laffont R, Vrielynck B, Fara, E.

841 2016. Gauging scale effects and biogeographical signals in similarity distance decay

842 analyses: an Early Jurassic ammonite case study. Palaeontology 59:671-687. DOI:

$843 \quad 10.1111 /$ pala. 12250. 
844 Zacaï A, Fara E, Brayard A, Laffont R, Dommergues J-L, Meister C. 2017. Phylogenetic

845 conservatism of species range size is the combined outcome of phylogeny and environmental 846 stability. Journal of Biogeography 44:2451-2462. DOI:10.1111/jbi.13043. 
Figure 1

Modern Nautilus

Living Nautilus in Palau. Photo source: Public domain image accessed from https://pxhere.com/en/photo/660195.

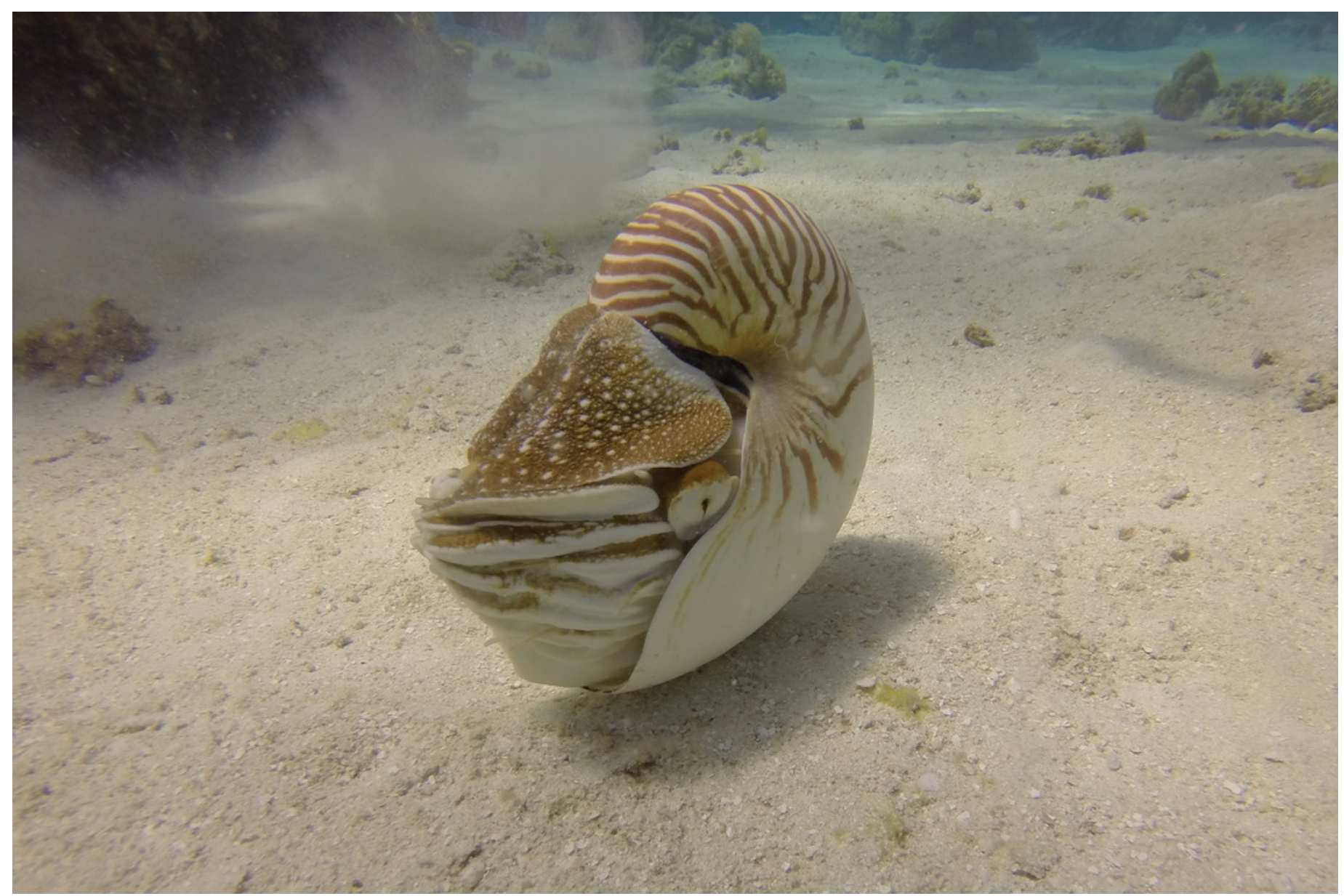




\section{Figure 2}

Relationship between shell form and postmortem buoyancy

Plot of first two principal coordinates derived from Reyment's 1973 analysis of five shell parameters (shell diameter, maximum inflation, body chamber length, ventral inflation, and umbilical width) on 42 Mesozoic ammonoid species (numbered circles). Each position on the plot reflects a particular shell shape. Reyment indicated predicted postmortem buoyancy of different shell forms on the plot, based on his experimental work that related shell shape parameters to buoyancy of the empty shell. Image source: Reyment (1973), fig. 32, p. 34. 


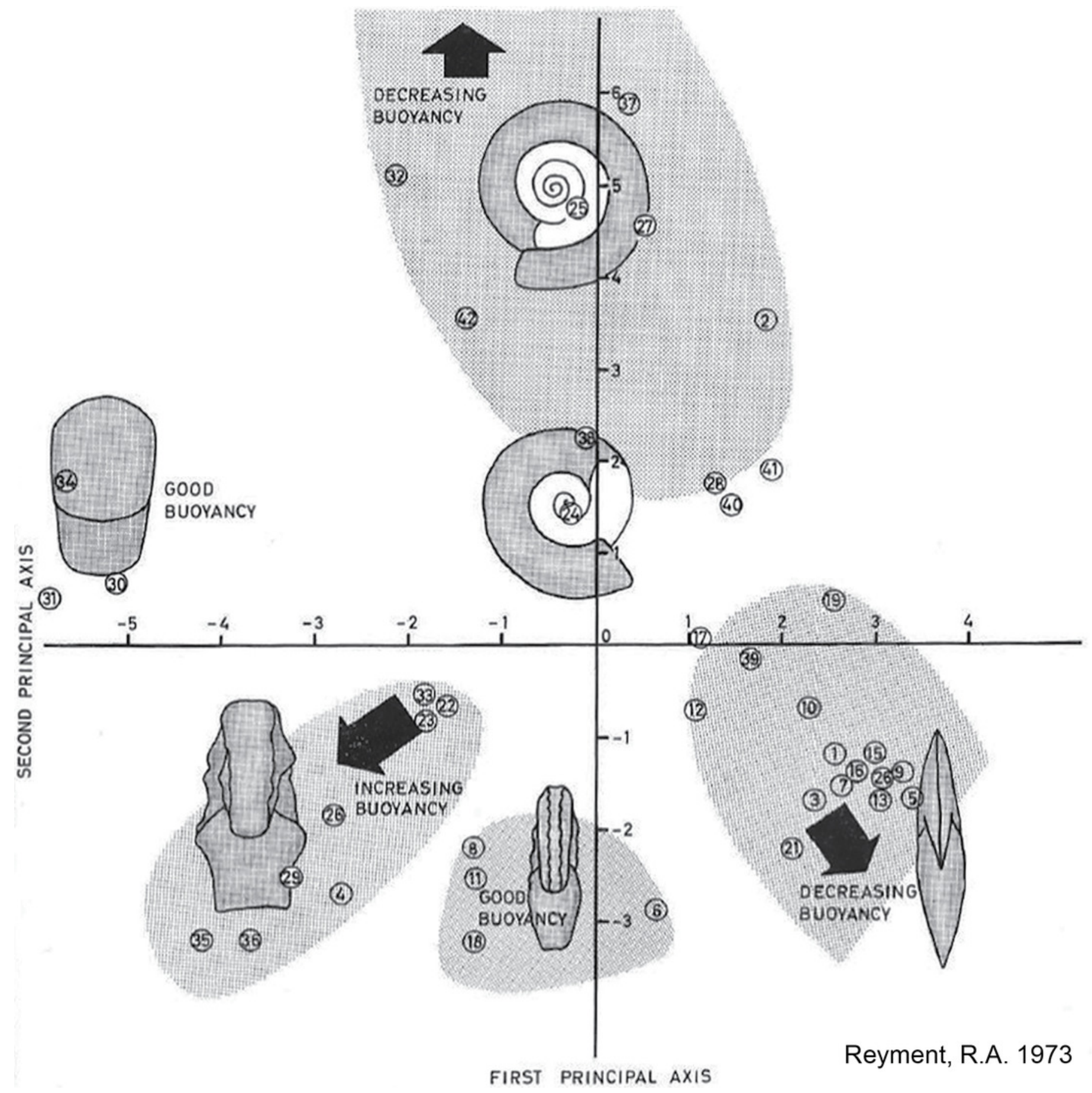


Figure 3 (on next page)

Westermann Morphospace

Schematic representation of Westermann Morphospace (Ritterbush \& Bottjer, 2012) as a ternary diagram. Each corner of the diagram represents the maximum value for one of the three shell shape parameters used to construct the morphospace: umbilical ratio $U$ (serpenticones), whorl thickness ratio Th (spherocones), and whorl expansion rate w (oxycones). Any planispiral shell form will plot within the ternary diagram based on its values for these three parameters. Note the similarity of Westermann morphospace to Reyment's (1973) principal coordinates plot (Fig. 2). 


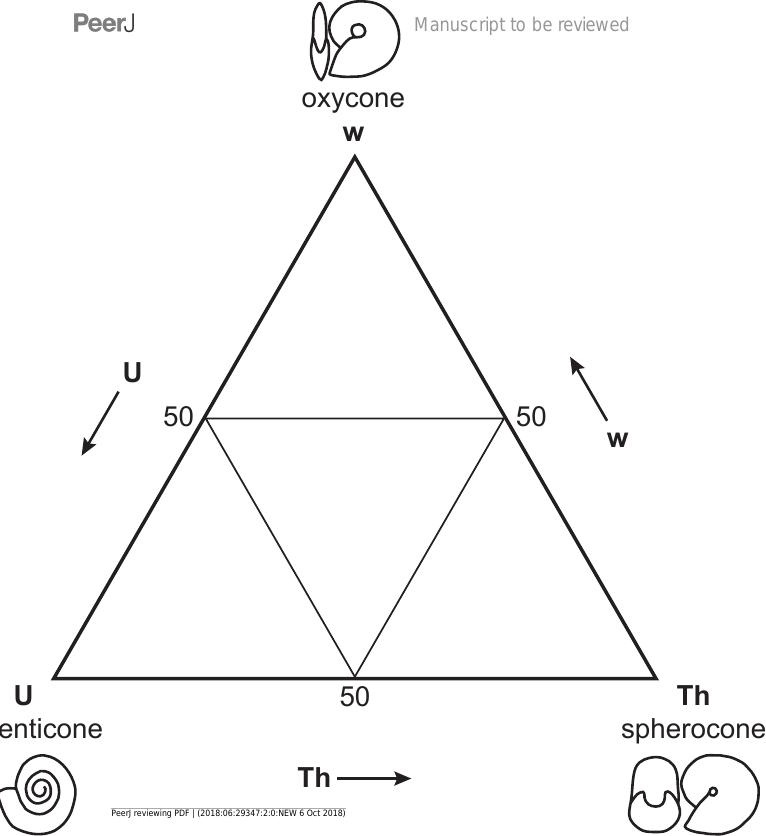




\section{Figure 4 (on next page)}

\section{Shell shape parameters}

Diagram showing definitions of measured parameters used to characterize ammonoid shell shape. a, height of last whorl; a', whorl height one-half-whorl back; b, breadth of last whorl; D, shell diameter; UD, umbilical diameter. 
b

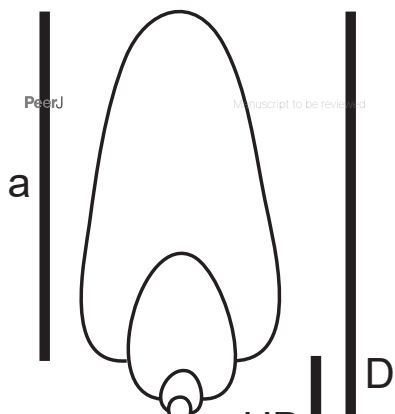




\section{Figure 5 (on next page)}

Buoyant vs. non-buoyant cephalopods in Westermann Morphospace.

Note that plots are inverted relative to Ritterbush and Bottjer's (2012) original ternary diagrams; this orientation is more standard for ternary diagrams. (A) Reyment's (1973) taxa (circles) and modern nautilids (dark blue squares) in Westermann Morphospace. Modern nautilids include Nautilus belauensis Saunders, 1981, N. macromphalus Sowerby, 1848, N. pompilius Linnaeus, 1758, and Allonautilus scrobiculatus Ward \& Saunders, 1997. Color coding indicates predicted postmortem buoyancy: buoyant-blue, intermediate-gray, not buoyant-orange. Light blue line represents a thickness ratio of $30 \%$, generally separating buoyant from non-buoyant shell forms. (B) Addition of ammonoid taxa reported in Ritterbush $\&$ Bottjer (2012; open circles). Most ammonoids fall within the non-buoyant postmortem field of morphospace. (C) Addition of Late Cenomanian and Early Turonian cephalopod genera (green squares). These taxa show a mix of shell forms predicted to be buoyant and nonbuoyant postmortem. 
Figure 6 (on next page)

Geographic range vs. shell shape

Scatterplots of geographic range (expressed as the $\log _{10}$ of the area in square kilometers spanned by each genus' occurrences) versus normalized thickness ratio (Th) (reflecting degree of shell compression for that genus). (A) Early Turonian genera. Correlation coefficient $r=0.161(p=0.355)$. (B) Late Cenomanian genera. Correlation coefficient $r=$ $0.117(p=0.459)$. 
$A$

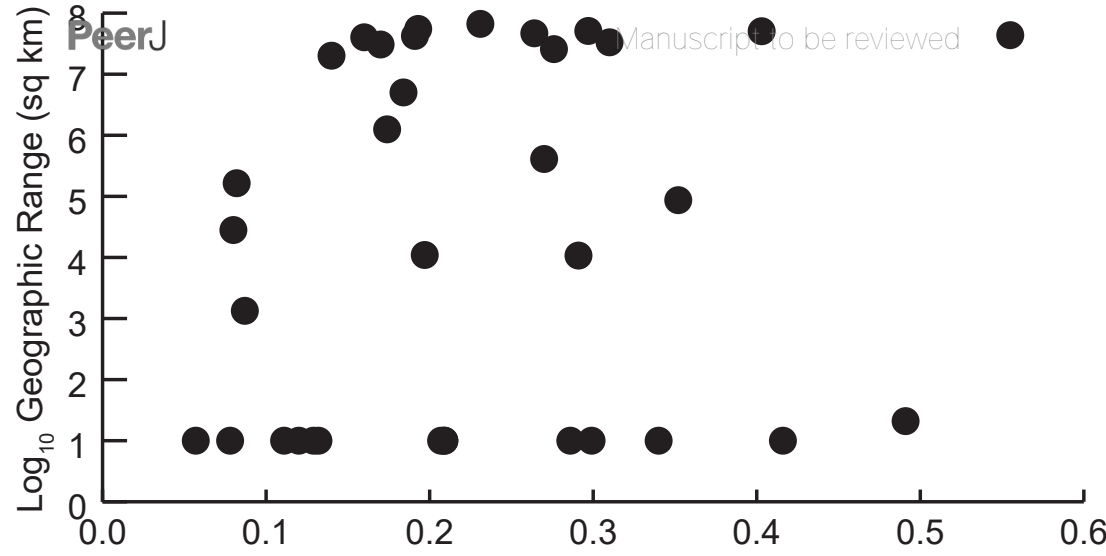

Normalized Th

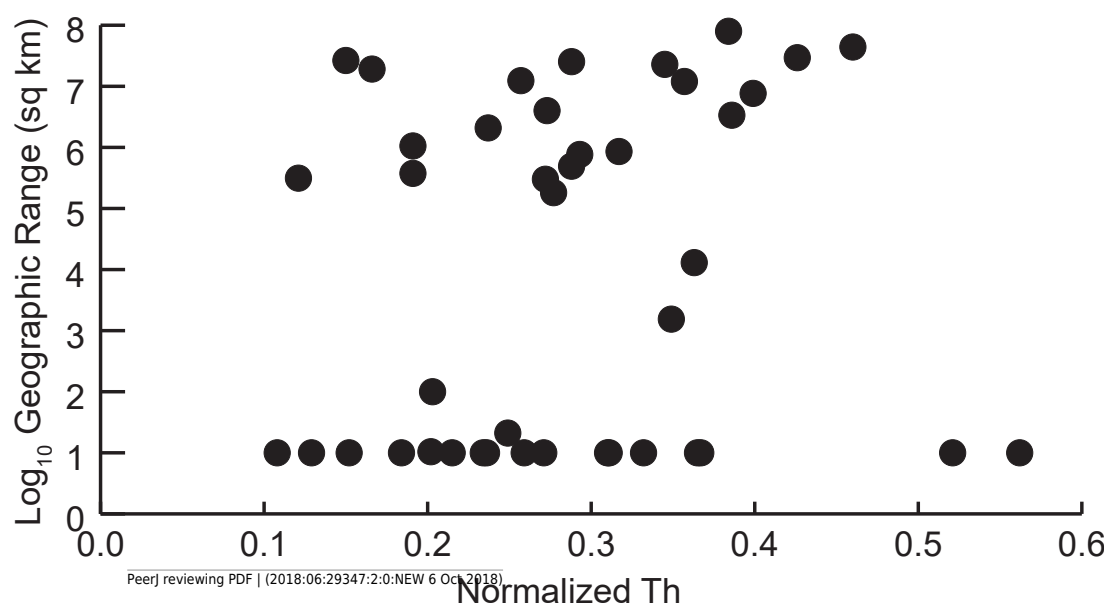


Figure 7 (on next page)

Distributions of geographic ranges for taxa with buoyant vs. non-buoyant postmortem shell forms

(A) Early Turonian genera. (B) Late Cenomanian genera. Distributions are not significantly different, implying that taxa with buoyant shell forms more likely to drift postmortem do not, in fact, show larger geographic ranges. 

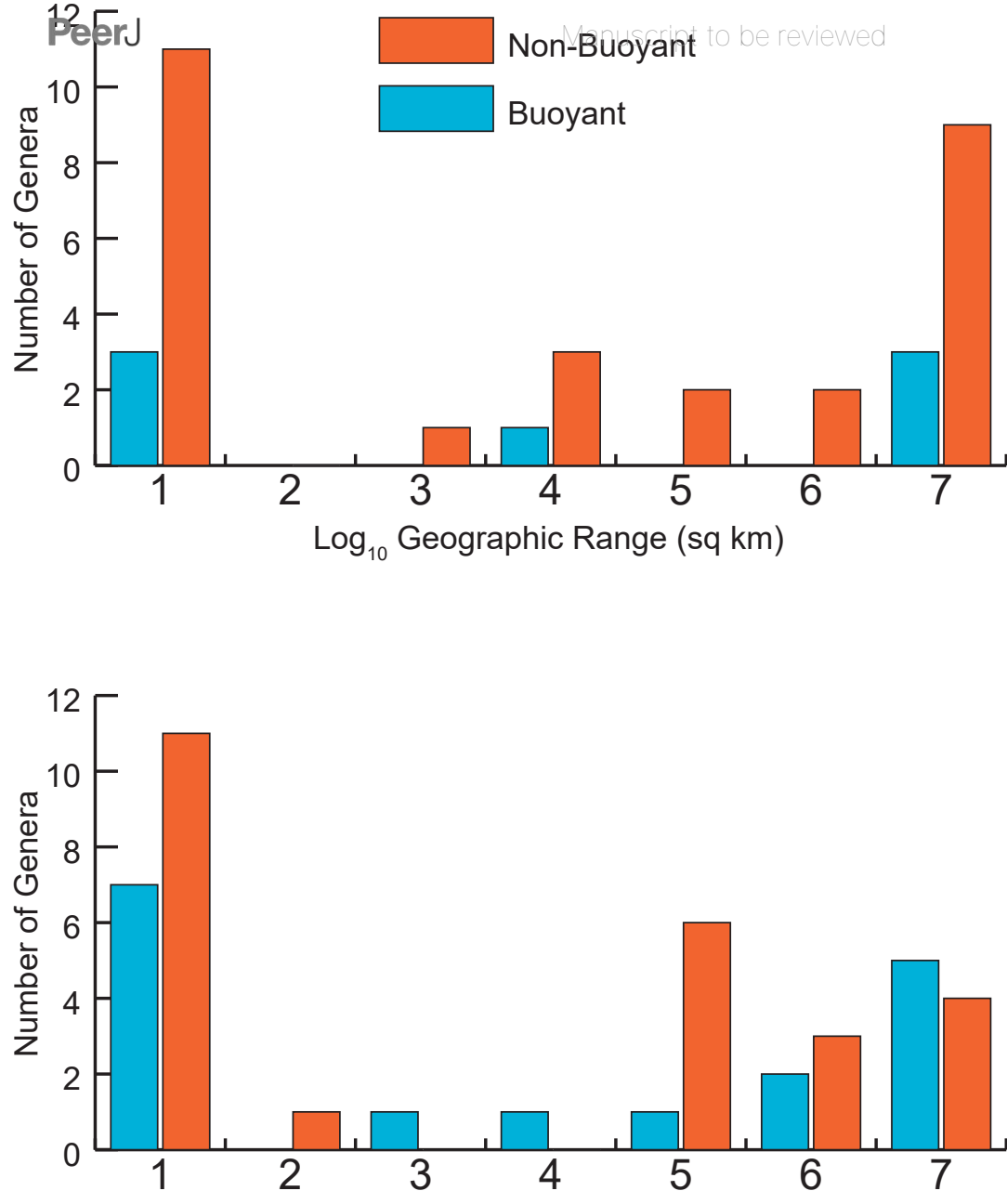

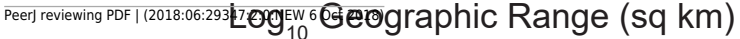




\section{Figure 8}

Geographic distributions of modern nautilid species

(A) All modern nautilid occurrences, including live specimens (orange) and dead shells (brown). Drifted shells span a larger area than known living occurrences. (B) Occurrences color-coded by species (live in lighter color, dead in darker color), with convex hulls enclosing all occurrences for each species. Most nautilid species do not have large geographic areas, even including shells that have drifted postmortem. The exception is N. pompilius, which has the largest range of drifted shells. The abundance of drifted shells in eastern Africa suggests the possibility of cryptic living populations of $N$. pompilius in the western Indian Ocean. Base map of Indo-Pacific region from ESRI (2016). Locality data from Toriyama et al. (1965) and House (1987). 

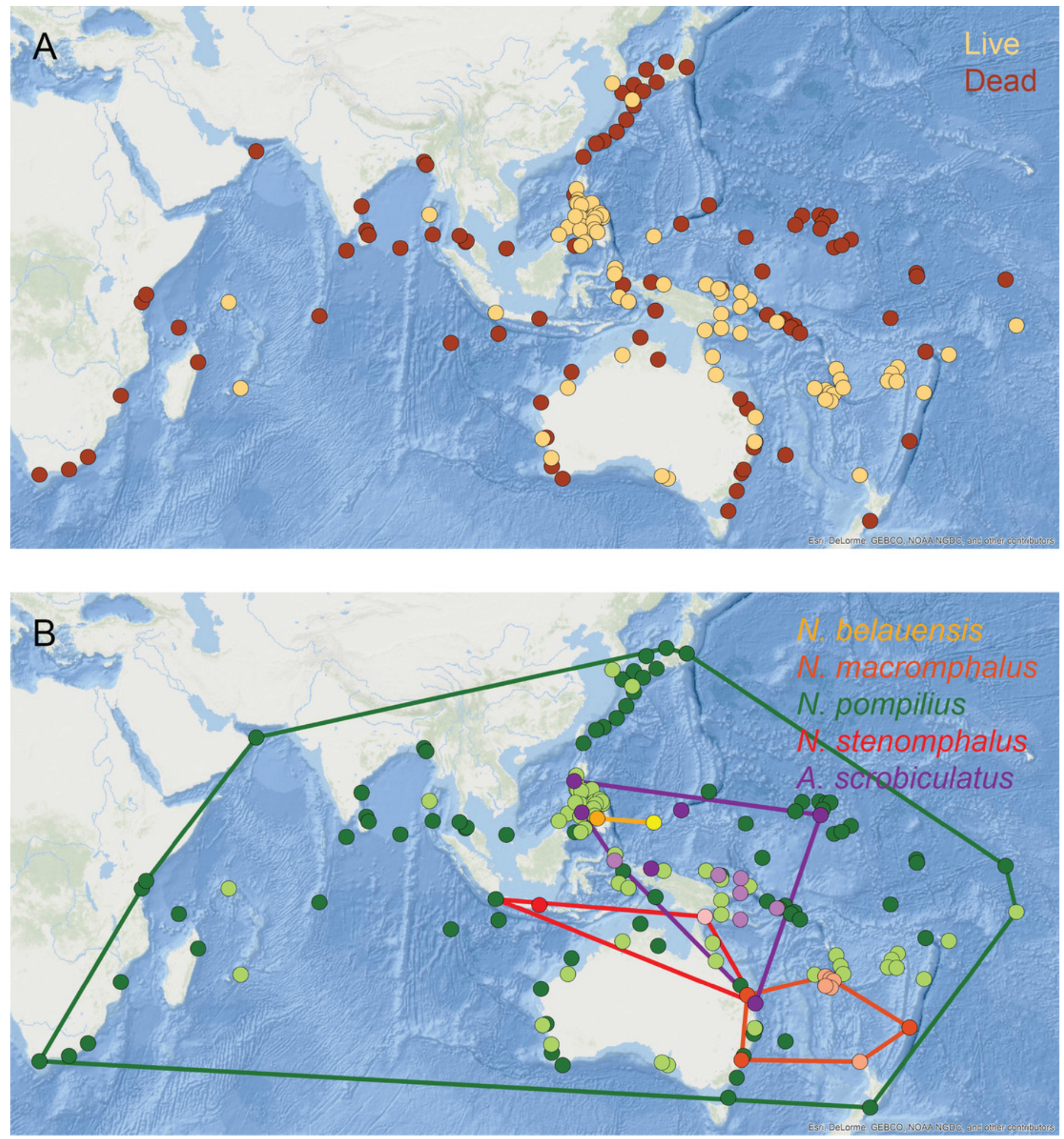


\section{Table $\mathbf{1}$ (on next page)}

Comparisons of median geographic range sizes for Late Cenomanian and Early Turonian cephalopod genera by buoyancy

Shells that are buoyant versus not buoyant postmortem are defined as having a normalized thickness ratio of more than versus less than $30 \%$ (see Fig. 5). 
1 Table 1: Comparisons of median geographic range sizes for Late Cenomanian and Early

2 Turonian cephalopod genera. Shells that are buoyant versus not buoyant postmortem are

3 defined as having a normalized thickness ratio of more than versus less than $30 \%$ (see Fig. 4).

4

\begin{tabular}{|l|c|c|c|}
\hline & $\begin{array}{c}\text { Median log } 10 \\
\text { geographic } \\
\text { range (sq km) }\end{array}$ & Count & $\begin{array}{c}\text { p(same median) } \\
\text { from Mann- } \\
\text { Whitney U-test }\end{array}$ \\
\hline $\begin{array}{l}\text { Late Cenomanian - } \\
\text { Buoyant }\end{array}$ & 4.11 & 17 & 0.589 \\
\hline $\begin{array}{l}\text { Late Cenomanian - } \\
\text { Not Buoyant }\end{array}$ & 5.26 & 25 & \\
\hline $\begin{array}{l}\text { Early Turonian - } \\
\text { Buoyant }\end{array}$ & 4.94 & 7 & \\
\hline $\begin{array}{l}\text { Early Turonian - } \\
\text { Not Buoyant }\end{array}$ & 4.24 & 28 & \\
\hline
\end{tabular}

5

6

7 


\section{Table 2 (on next page)}

Comparisons of median geographic range sizes for Late Cenomanian and Early Turonian cephalopod genera by mode of life and buoyancy

Mode of life is based on position within Westermann Morphospace, following Ritterbush \& Bottjer (2012). No vertical migrants were predicted to be non-buoyant postmortem and no nektonic forms were predicted to be buoyant postmortem, based on their normalized thickness ratios (see Fig. 5). 
1 Table 2: Comparisons of median geographic range sizes for Late Cenomanian and Early

2 Turonian cephalopod genera by mode of life. Mode of life is based on position within

3 Westermann Morphospace, following Ritterbush \& Bottjer (2012). No vertical migrants were

4 predicted to be non-buoyant postmortem and no nektonic forms were predicted to be buoyant

5 postmortem, based on their normalized thickness ratios (see Fig. 5).

6

\begin{tabular}{|l|c|c|c|}
\hline \multirow{2}{*}{ Nektonic } & $\begin{array}{c}\text { Median } \log _{10} \\
\text { geographic } \\
\text { range (sq km) }\end{array}$ & Count & $\begin{array}{c}\text { p(same median) } \\
\text { from Kruskal- } \\
\text { Wallis test }\end{array}$ \\
\hline Demersal & 1.32 & 17 & \multirow{2}{*}{0} \\
\cline { 1 - 2 } Vertical migrant & 3.61 & 32 & \multirow{2}{*}{0.323} \\
\cline { 1 - 3 } & 7.47 & 9 & \\
\hline
\end{tabular}

7

8

9 


\section{Table 3(on next page)}

Geographic range sizes of modern nautilids

Range sizes are represented as the area in square kilometers of convex hulls around nautilid occurrences (Fig. 8B). 
1 Table 3: Geographic range sizes of modern nautilids. Range sizes are represented as the area

2 in square kilometers of convex hulls enclosing nautilid occurrences (Fig. 8B).

3

\begin{tabular}{|l|c|c|}
\hline Species & $\begin{array}{c}\text { Living geographic range } \\
\text { (sq km) }\end{array}$ & $\begin{array}{c}\text { Living geographic range } \\
\text { plus drift shells (sq km) }\end{array}$ \\
\hline Allonautilus scrobiculatus & $1,458,480$ & $11,808,955$ \\
\hline Nautilus belauensis & 500 & 2,200 \\
\hline N. macromphalus & 185,977 & $4,369,601$ \\
\hline N. stenomphalus & $3,713,991$ & $3,713,991$ \\
\hline N. pompilius & $76,428,763$ & $131,322,000$ \\
\hline
\end{tabular}

4

5

6

7

8 